\title{
Nervous system complications of herpes zoster: immunofluorescent demonstration of varicella-zoster antigen in CSF cells
}

\author{
A.C.B.PETERS, J. VER T TE G, G. T H.A.M.B OT S, \\ J. L I N D E M A N, A N D R. E. H. SMEETS
}

From the Departments of Neurology, Pathology, and Neuropathology, and the Laboratory of Medical Microbiology, University Hospital, Leiden, The Netherlands

SUMMARY In nine out of 11 patients with herpes zoster and neurological symptoms varicella-zoster antigen was demonstrated in CSF cells by indirect immunofluorescent staining. Cerebrospinal fluid cytology was in most cases highly suggestive of viral infection. This study demonstrates the value of both immunofluorescent staining on CSF cells and CSF cytology, as corroboration of an otherwise exclusively serologically based virological diagnosis.

The concept that varicella (chickenpox) and herpes zoster (shingles) might be caused by the same agent (varicella-zoster virus) was postulated by Von Bokay (1909). Tissue culture and antibody studies have confirmed this hypothesis (Weller, 1953; Weller and Coons, 1954; Weller et al., 1958; TaylorRobinson, 1959). Complications of the respective diseases as they affect the central nervous system (CNS) are widely divergent (McKendall and Klawans, 1978).

In herpes zoster symptoms of neurological involvement are well documented (Appelbaum et al., 1962; Gardner-Thorpe et al., 1976; McKendall and Klawans, 1978), but there is a remarkable paucity of virological studies of the cerebrospinal fluid (CSF). The first laboratory evidence that varicella-zoster (VZ) virus may be present in the CSF was reported by Evans and Melnick (1949) who, in an electronmicroscopic study, observed morphologically similar particles in vesicular fluid and in the CSF of a patient with herpes zoster. The VZ virus has been isolated from CSF in only five cases with herpes zoster (Gold, 1966; Joncas et al., 1968; Djupesland et al., 1976; Hotson and Pedley, 1976). The VZ antigen has been demonstrated in CSF cells in one case of herpes zoster meningitis (Shoji et al., 1976).

As CNS involvement in herpes zoster is not infrequent, and morbidity and mortality are not

Address for reprint requests: Dr A. C. B. Peters, Department of Neurology, University Hospital, Leiden, The Netherlands.

Accepted 16 November 1978 negligible (Gardner-Thorpe et al., 1976; McKendall and Klawans, 1978), in particular in immunodepressed patients (Feldman et al., 19730 Hotson and Pedley, 1976; Levin and Zaia, 1977) the need for accurate virological diagnosis need no emphasis. Isolation of the VZ virus from the CSF is unequivocal diagnostic proof, but the demonstration of the VZ antigen in CSF cells by immunofluorescence is equally convincing evidence for viral CNS infection (Sommerville, 1966; Dayan and Stokes, 1973; Taber et al., 1973, 1976; Lindeman et al., 1974; Peters et al., 1978a, b).

In the present report we present the results of immunofluorescent staining of CSF cells in 11 patients with herpes zoster showing neurological symptoms. We review the literature on virological CSF studies in nervous system complications of herpes zoster and make suggestions for further investigations in the clinical setting.

\section{Methods}

Studies on the CSF included total and differential cell count, protein and glucose estimation, and preparation of slides for cytological examination and immunofluorescent staining (Peters et al., $1978 \mathrm{a}, \mathrm{b})$. Virus isolations from CSF were attempted by inoculating cultures of human embryonic diploid cells and primary monkey kidney cells. In some cases suckling mice were inoculated to exclude the presence of Coxsackie viruses.

Antiserum to varicella-zoster virus was prepared 
by immunising three rabbits with purified viral antigen mixed with Freund's complete adjuvant. The antigen used was prepared by alkalinic extraction of infected human diploid lung fibroblasts. The titre of all three sera was satisfactory. For convenience the sera were pooled before purification. To overcome nonspecific binding with human tissue in the indirect immunofluorescent test the serum was adsorbed from liver powder and $\mathrm{A}, \mathrm{B}, \mathrm{O}$, and $\mathrm{Rh}$ antigens from human blood.

Antirabbit gammaglobulin was prepared by immunising goats with purified rabbit gammaglobulin. The antibody titre and the specificity of the reaction were tested in immunodiffusion plates. After conjugation with FITC the sera were adsorbed with liver powder and lyophilised in $1.0 \mathrm{ml}$ aliquots (Peters et al., 1978b). Immunofluorescence (IMF) tests were performed on the CSF slides by the indirect method: positive and negative control slides were included in the tests (Peters et al., 1978a, b). All slides were numbered and the results were read blind. In slides with a low cell count (cf. our cases 9 and 10) a minimal score of three positive cells with a typical fluorescence (intranuclear or intranuclear and cytoplasmic in VZ cases) was considered as a positive result of the immunofluorescent test. Paired serum samples were examined for complement fixing antibodies against mumps, Sendai, Herpes virus hominis $(H V H)$, cytomegalovirus, varicella-zoster virus, Coxsackie A and B and ECHO viruses (Peters $e t$ al., 1978a).

\section{Patients}

The 11 case histories are summarised in Table 1 . More detailed descriptions of three cases are presented to illustrate the various types of neurological complications.

\section{CASE 1}

On 20 March 1977 a 13 year old schoolboy noticed tickling in the left side of his tongue. Left facial weakness developed the next day. On examination a left lower motor neurone facial paralysis was present. Vesicles were noticed on the left side of the tongue and the soft palate. Lacrimation was partially lost on the left side. The CSF protein level was $0.22 \mathrm{~g} / 1$, with slight pleiocytosis (six mononuclear cells per $\mathrm{mm}^{3}$ ). Improvement had occurred by February 1978 with incomplete recovery of the facial palsy.

\section{CASE 4}

A 76 year old retired carpenter developed a painful, vesicular eruption on the right side of his forehead with red and swollen eyelids in September 1977. Simultaneously he became bradyphrenic, and deterioration of vision in the right eye was noticed.

On admission to hospital in November 1977 he was drowsy and bradyphrenic. Snout and suckling reflexes were present. The right optic disc was pale. The right pupil was larger and reacted to light more sluggishly than the left. Examination of vision was unreliable. Right sided oculomotor palsy and lower motor neurone facial weakness were present. Diminished sensation in the ophthalmic and maxillary divisions of the trigeminal nerve was suspected. The right foot dragged along the ground and there was an extensor plantar response on the right side. The CSF contained 17 mononuclear cells per $\mathrm{mm}^{3}$, and CSF protein level was $0.55 \mathrm{~g} / 1$. The EEG showed excess slow wave activity over both hemispheres, most marked over the left temporal region. The CAT scan revealed a slight diffuse loss of brain parenchyma and a left parietal low density area. A presumed viral pneumonia complicated the clinical course, and the patient died in January 1978. Postmortem examination was refused.

CASE 8

A 44 year old man received a kidney transplant in March 1977. Postoperative medication included azathioprine and prednisone. In April 1977 he developed a vesicular rash in the right T10 dermatome. On 6 May 1977 he had a generalised convulsion and was admitted to hospital. On examination, neurological signs were absent. The right T10 dermatome showed encrustations and some vesicles. The CSF examination revealed 53 mononuclear cells per $\mathrm{mm}^{3}$ and protein content of $0.59 \mathrm{~g} / \mathrm{l}$. The EEG showed bursts of spike-wave complexes bilaterally. The CAT scan was within normal limits. The clinical course was uncomplicated.

\section{Results}

Clinical data, CSF and virological studies are summarised in Tables 1 and 2 respectively. No virus was isolated from the CSF.

In cases 1-4 and 7-10 VZ antigen in CSF cells was demonstrated by intranuclear (Fig. 1) or intranuclear and cytoplasmic fluorescence. Cases 5 and 6 were negative with this method.

\section{Discussion}

The only other available record on IMF demonstration of VZ antigen in CSF cells describes one positive case out of five patients with herpes zoster meningitis (Shoji et al., 1976). 
Table 1 Clinical data

\begin{tabular}{|c|c|c|c|c|c|c|}
\hline \multirow[t]{2}{*}{ Case } & \multirow{2}{*}{$\begin{array}{l}\text { Age } \\
(y r)\end{array}$} & \multirow[t]{2}{*}{$\operatorname{Sex}$} & \multirow{2}{*}{$\begin{array}{l}\text { Localisation of vesicular } \\
\text { eruption }\end{array}$} & \multicolumn{2}{|c|}{ Neurological complications } & \multirow[t]{2}{*}{ Comments } \\
\hline & & & & $\begin{array}{l}\text { Onset (days after } \\
\text { eruption) }\end{array}$ & Symptoms & \\
\hline 1 & 13 & $\mathbf{M}$ & Left side tongue, soft palate & Simultaneous & VII, left & \\
\hline $2^{*}$ & 54 & $\mathbf{F}$ & $V(1)$, left & 11 & $\begin{array}{l}\text { VII, left } \\
\text { V? (masseter reflex } \downarrow \text { ) }\end{array}$ & $\begin{array}{l}\text { CSF collection one week before } \\
\text { neurological symptoms! }\end{array}$ \\
\hline $3 \dagger$ & 71 & $\mathbf{F}$ & Auricle, left & Simultaneous & VII, left & \\
\hline 4 & 76 & $\mathbf{M}$ & $\mathrm{V}(1,2)$, right & \pm 60 & $\begin{array}{l}\text { Drowsiness; bradyphrenia ; } \\
\text { n. II, III, V }(1,2) \text {, VII, right } \\
\text { Babinski right }\end{array}$ & \\
\hline 5 & 12 & $\mathrm{~F}$ & Right side tongue, auricle & \pm 20 & $\begin{array}{l}\text { VII, right } \\
\text { VIII? } \\
\text { nystagmus, vertigo }\end{array}$ & \\
\hline 6 & 75 & $\mathbf{M}$ & $V(1)$, left & $=30$ & $\begin{array}{l}\text { Bradyphrenia; drowsiness; } \\
\text { disorientation } \\
\text { II?, left } \\
\text { V (1), left }\end{array}$ & \\
\hline 7 & 44 & $\mathbf{M}$ & T10, right & \pm 10 & Seizure & \\
\hline 8 & 74 & $\mathbf{M}$ & L3-4, left & \pm 10 & $\begin{array}{l}\text { Leg weakness and wasting } \\
\text { (in particular quadriceps } \\
\text { muscle), left }\end{array}$ & $\begin{array}{l}\text { Biopsy m. quadriceps: denerva- } \\
\text { tion atrophy (with marked } \\
\text { type-grouping) }\end{array}$ \\
\hline 9 & 55 & $\mathbf{F}$ & No vesicles? pain in right ear & - & VII, right & Zoster sine herpete? \\
\hline 10 & 40 & $\mathbf{M}$ & $\mathrm{C5}$, left & \pm 10 & $\begin{array}{l}\text { Arm weakness, left, in par- } \\
\text { ticular biceps and deltoid } \\
\text { muscle; biceps, triceps, radial } \\
\text { jerk reflexes negative. }\end{array}$ & $\begin{array}{l}1974 \text { kidney transplantation. } \\
\text { May } 1978 \text { tumour cerebri; } \\
\text { radiotherapy; azathioprine } \\
\text { prednisone. }\end{array}$ \\
\hline 11 & 51 & $F$ & T8-9, left & 6 & $\begin{array}{l}\text { Weakness leg, left } \\
\text { (distal > proximal) }\end{array}$ & \\
\hline
\end{tabular}

*Municipal Hospital, The Hague.

†University Hospital Dijkzigt, Rotterdam.

Success and failure to detect virus antigen in CSF cells by the IMF technique have also been reported in HVH encephalitis (Marshall, 1967; Dayan and Stokes, 1973; Longson et al., 1973; Tomlinson and MacCallum, 1973; Jarratt and Hubler, 1974; Olding-Stenkvist, 1974; Spaar, 1976; Taber et al., 1976; Grumbach et al., 1977).

The variability of the results obtained in attempts to demonstrate antigen in CSF cells in $\mathrm{VZ}$ and $\mathrm{HVH}$ associated CNS disease, seems to agree with the rarely successful isolation from CSF of the agents belonging to the herpes virus group (VZ, HVH, Cytomegalovirus). Isolation of VZ virus from CSF is rarely successful. In three patients with zoster encephalitis, zoster oticus with facial palsy, and herpes zoster as complication of cardiac transplantation respectively, VZ virus isolation from CSF has been recorded (Joncas et al., 1968; Djupesland et al., 1976; Hotson and Pedley, 1976). Other isolations have been reported from two patients with herpes zoster without neurological symptoms but with headache and CSF pleiocytosis (Gold, 1966).

The source of the VZ virus in the CSF is still an unresolved problem. Firstly, it may represent a recrudescence of latent varicella virus in the dorsal root or cranial ganglia (Hope-Simpson,
1965; Bastian et al., 1974; Shibuta et al., 1974) with subsequent spread to the CSF. Direct proof of latent varicella virus in the ganglia has yet to be adduced (Plotkin et al., 1977). Secondly, infection by exogenous virus may occur in rare instances (Berlin and Campbell, 1970). Thirdly, haematogenous spread cannot be excluded. A viraemic phase, with isolation of VZ virus, has been reported in immunodepressed children with herpes zoster (Feldman and Epp, 1976).

Pleiocytosis of CSF in zoster patients is common, even in the absence of neurological symptoms (Appelbaum et al., 1962; McKendall and Klawans, 1978), but cytological examinations have not been reported, so far as we are aware. In most of our cases CSF cytology revealed lymphocytosis, polymorphism of the lymphoid cell series, atypical lymphocytes with protrusions of nuclei, monocytes with cloverleaf shaped metaplastic nuclei, and occasionally plasma cells (Fig. 2, Table 2). In case 2, lymphocytes with an unusual abundance of cytoplasm were seen. Although not pathognomonic, this picture is highly suggestive of viral infection particularly if tuberculous meningitis, neurosyphilis, CNS sarcoidosis, and multiple sclerosis are excluded.

Results of CSF cytology correlated well with 


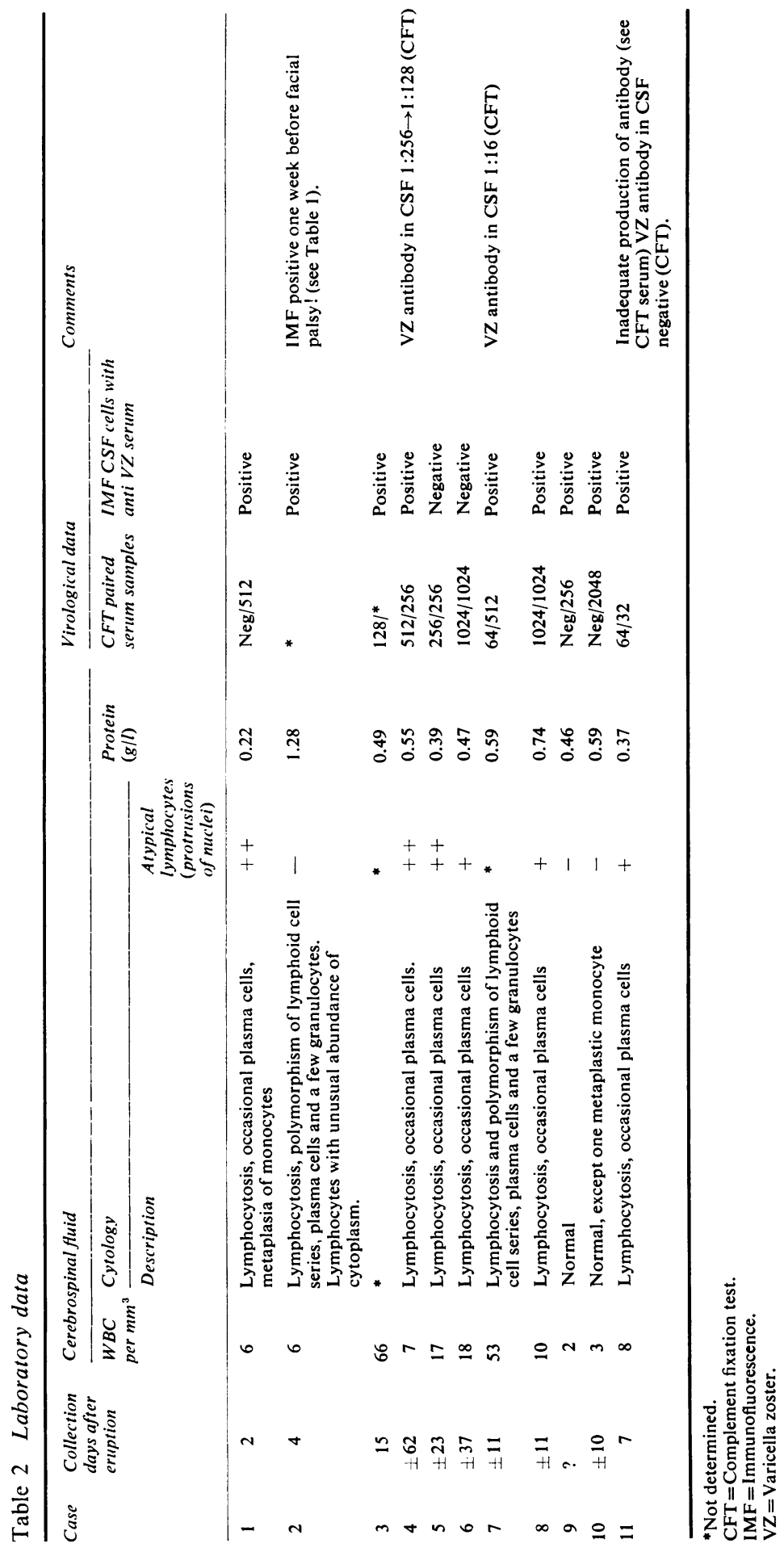




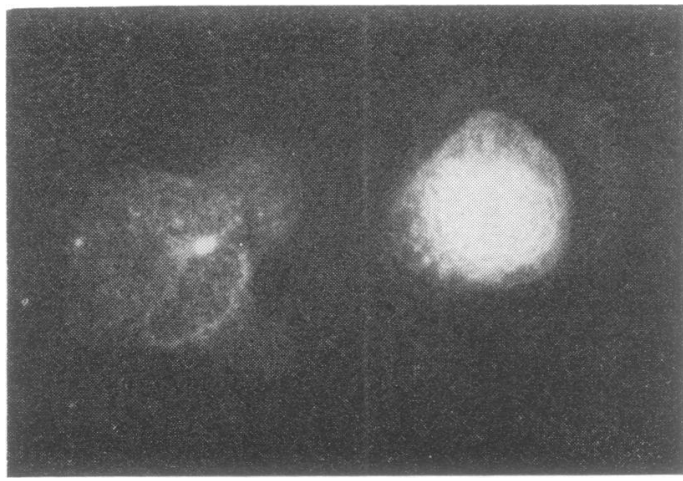

Fig. 1 CSF cell with intranuclear fluorescence with anti-VZ serum (original magnification $\times 500$ ); left: negative cell.

the presence of VZ antigen in CSF cells (Table 2), underlining the value of this relatively simple method. The presence of VZ antibodies in the CSF will not always imply complete antigen blocking, as could be concluded from our cases 4 and 7 (Table 2) with immunofluorescent demonstration of VZ antigen in CSF cells. Djupesland et al. (1976) reported a case where VZ virus was isolated from CSF and a substantially increased complement fixing antibody titre was found against the virus in the CSF. Varicella-zoster antibodies in the CSF of patients with neurological complications of herpes zoster have been reported in only a few cases (Juel-Jensen and MacCallum, 1972; Djupesland et al., 1976; Bieger et al., 1977).

In most reports on neurological complications of herpes zoster, virological diagnosis has been made solely on complement fixation tests. This study demonstrates the value of both IMF staining on CSF cells and CSF cytology in the corroboration of an otherwise exclusively serologically based virological diagnosis. Table 2 (cases 9 and 10) shows that a normal cell count and cytogram does 0 not exclude the presence of $\mathrm{VZ}$ antigen in CSF cells, emphasising the desirability of performing IMF staining as well.

Finally, antiviral chemotherapy in zoster en-: cephalitis is probably of some value (Juel-Jensen $\stackrel{5}{\rightarrow}$ and MacCallum, 1972). If this is so, there is little $\bar{c}$ doubt that a firmly established diagnosis at the 음 earliest opportunity is essential. Immunofluor- के escence of CSF cells may identify VZ antigen within hours of CSF sampling.

We would like to thank Dr A. R. Wattendorf and $\vec{\circ}$ Dr P. M. Bakker, Municipal Hospital, The Hague, and Dr J. van Gijn, University Hospital Dijkzigt, $\vec{\omega}$ Rotterdam for providing CSF samples and clinical information, and Mrs Inet de Jonge-vd Weele for secretarial support.

\section{References}

Appelbaum, G., Kreps, S. I., and Sunshine, A. (1962). Herpes zoster encephalitis. American Journal of Medicine, 32, 25-31.

Bastian, F. O., Rabson, A. S., Yee, C. L., and Tralka T. S. (1974). Herpes virus varicella isolated frope human dorsal root ganglia. Archives of Pathology. $\overrightarrow{0}$ 97, 331-333.

Berlin, B. S., and Campbell, T. (1970). HospitaF acquired herpes zoster following exposure to chickenpox. Journal of the American Medical Association, 211, 1831-1833.

Bieger, R. C., Van Scoy, R. E., and Smith, T. F. (1977). Antibodies to varicella-zoster in cerebro-

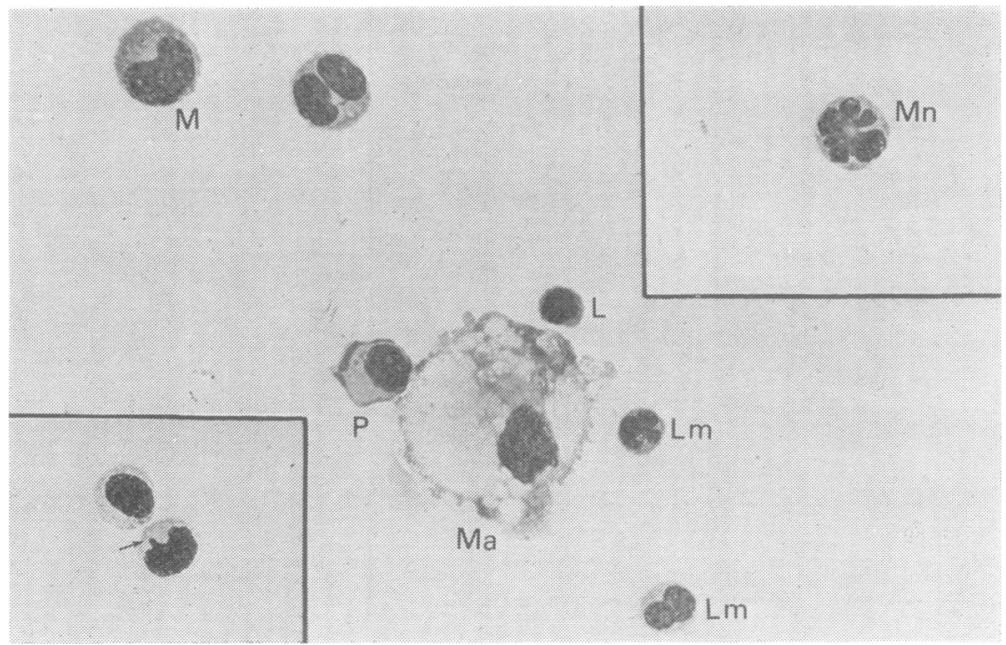

Fig. 2 CSF cytogram: normal monocyte $(M)$ and monocyte with clover leaf shaped nucleus $(M n)$, lymphocyte $(L)$, lymphocytes with polymorphism of nuclei $(\mathrm{Lm})$, and nucleus with protrusion (arrow), macrophage $(\mathrm{Ma})$, plasmacytoid cell $(P)$ (photomicrograph $\times 500)$. 
spinal fluid. Archives of Neurology (Chicago), 34, 489-491.

Dayan, A. D., and Stokes, M. J. (1973). Rapid diagnosis of encephalitis by immunofluorescent examination of cerebrospinal fluid cells. Lancet, 1, 177-179.

Djupesland, G., Berdal, P., Johannessen, F. A., Degré, M. Stien, R., and Skrede, S. (1976). Viral infection as a cause of acute peripheral facial palsy. Archives of Otolaryngology, 102, 403-406.

Evans, A. S., and Melnick, J. L. (1949). Electronmicroscope studies of the vesicle and spinal fluids from a case of herpes zoster. Proceedings of the Society for Experimental Biology and Medicine (NY), 71, 283-286.

Feldman, S., Hughes, W. T., and Kim, H. Y. (1973). Herpes zoster in children with cancer. American Journal of Diseases of Children, 126, 178-184.

Feldman, S., and Epp, E. (1976). Isolation of varicellazoster virus from blood. Journal of Pediatrics, 88, 265-267.

Gardner-Thorpe, C., Foster, I. B., and Barwick, D. D. (1976). Unusual manifestations of herpes zoster. Journal of the Neurological Sciences, 28, 427-447.

Gold, E. (1966). Serologic and virus-isolation studies of patients with varicella or herpes-zoster infection. New England Journal of Medicine, 274, 181-185.

Grumbach, K., Boringer, J. R., and Klassen, T. (1977). Herpes-simplex antigen in rabbit cerebrospinal fluid. Lancet, 1, 149.

Hope-Simpson, R. E. (1965). The nature of herpeszoster: a long term study and a new hypothesis. Proceedings of the Royal Society of Medicine, 58, 9-20.

Hotson, J. R., and Pedley, T. A. (1976). The neurological complications of cardiac transplantation. Brain, 99, 673-694.

Jarratt, M., and Hubler, W. R. (1974). Herpes genitalis and aseptic meningitis. Archives of Dermatology, 110, 771-772.

Joncas, J., Lussier, G., Podoski, M. O., and Rona, S. (1968). Zoster encephalitis: a case report. Canadian Journal of Public Health, 59, 484 486.

Juel-Jensen, B. E., and MacCallum, F. O. (1972). Herpes simplex, Varicella and Zoster: Clinical manifestations and treatment. Heinemann: London.

Levin, M. J., and Zaia, J. A. (1977). Immunosuppression and infection-progress? New England Journal of Medicine, 296, 1406-1408.

Lindeman, J., Müller, W. K., Versteeg, J., Bots, G. T. A. M., and Peters, A. C. B. (1974). Rapid diagnosis of meningoencephalitis, encephalitis. Neurology (Minneapolis), 24, 143-148.

Longson, M., Liversedge, L. A., and Wilkinson, I. M. S. (1973). Diagnosis of virus encephalitis. Lancet, 1, 371.

Marshall, W. J. S. (1967). Herpes simplex encephalitis treated with idoxuridine and external decompression. Lancet, 2, 579-580.

McKendall, R. R., and Klawans, H. L. (1978). Nervous system complications of varicella-zoster virus. In Handbook of Clinical Neurology, vol. 34, pp. 161-184. Edited by P. J. Vinken and G. W. Bruyn. North-Holland: Amsterdam.
Olding-Stenkvist, E. (1947). Acute necrotizing Herpes simplex virus encephalitis-diagnostic problems. Scandinavian Journal of Infectious Diseases, 6, 355360.

Peters, A. C. B., Versteeg, J., Lindeman, J., and Bots, G. T. A. M. (1978a). Viral meningoencephalitis and head injury. Acta Neurologica Scandinavica, 57, 77-87.

Peters, A. C. B., Versteeg, J. Bots, G. T. A. M., and Lindeman, J. (1978b). Varicella and acute cerebellar ataxia. Archives of Neurology (Chicago), 35, 769-771.

Plotkin, S. A., Stein, S., Snyder, M., and Immesoete, P. (1977). Attempts to recover varicella virus from ganglia. Annals of Neurology, 2, 249.

Shibuta, H., Ishikaura, T., Hondo, R., Aoyama, Y., Kurata, K., and Matumoto, M. (1974). Varicella virus isolation from spinal ganglia. Archiv für die gesamte Virusforschung, 45, 382-385.

Shoji, H., Koya, M., and Ogiwara, H. (1976). Meningitis associated with herpes zoster. Journal of Neurology, 213, 269-271.

Sommerville, R. G. (1966). Rapid identification of neurotropic viruses by an immunofluorescence technique applied to cerebrospinal fluid cellular deposits. Archiv für die gesamte Virusforschung, 19, 63-69.

Spaar, F. W. (1976). Die menschliche Herpes-SimplexEncephalitis und Meningitis. Gustav Fischer Verlag: Stuttgart, New York.

Taber, L. H., Mirkovic, R. R., Adam, V., Ellis, S. S., Yow, M. D., and Melnick, J. L. (1973). Rapid diagnosis of enterovirus meningitis by immunofluorescent staining of CSF leukocytes. Intervirology, 1, 127-134.

Taber, L. H., Brasier, F., Couch, R. B., Greenberg, S. B., Jones, D., and Knight, V. (1976). Diagnosis of herpes simplex virus infection by immunofluorescence. Journal of Clinical Microbiology, 3, 309-312.

Taylor-Robinson, D., and Downie, A. W. (1959). Chickenpox and herpes zoster I. Complementfixation studies. British Journal of Experimental Pathology, 40, 398.

Tomlinson, A. H., and MacCallum, F. O. (1973). Virus antigen in cells of lumbar cerebrospinal fluid. Lancet, 1, 319-320.

Von Bokay, J. (1909). UUber den Ätiologischen Zusammenhang der Varizellen Mit Gewissen Fällen von Herpes Zoster. Wiener Klinische Wochenschrift, 22, 1323-1326.

Weller, T. H. (1953). Serial propagation in vitro of agents producing inclusion bodies derived from varicella and herpes zoster. Proceedings of the Society for Experimental Biology and Medicine $(N Y), 83,340-346$.

Weller, T. H., and Coons, A. H. (1954). Fluorescent antibody studies with agents of varicella and herpes zoster propagated in vitro. Proceedings of the Society for Experimental Biology and Medicine, 86, 789.

Weller, T. H., Witton, H. M., and Bell, E. J. (1958). The etiologic agents of varicella zoster: isolation, propagation, and cultural characteristics in vitro. Journal of Experimental Medicine, 108, 843-869. 